\title{
JENIS PARAGRAF DALAM SURAT KABAR ONLINE CNN INDONESIA BERTEMA VIRUS CORONA
}

\author{
Nurlaely Aulia ${ }^{1}$,Zaini Abdul Bahza ${ }^{2}$ Goziyah $^{3}$ \\ Universitas Muhammadiyah Tangerang \\ aulianurlaely@gmail.com ${ }^{1}$, zainiabdul2000@gmail.com ${ }^{2}$, tiasagoziyah@yahoo.com ${ }^{3}$
}

\begin{abstract}
Abstrak
Penelitian ini bertujuan untuk menganalisis jenis paragraf yang terdapat pada dua surat kabar online CNN Indonesia yang bertema virus corona. Penelitian ini menggunakan pendekatan kualitatif dan metode analisis isi untuk menganalisis jenis paragraf. Dalam penelitian ini sumber data yang digunakan sebagai objek analisis menggunakan dua sumber data yaitu dua teks berita yang berjudul "Telkom Konfirmasi Suspect Virus Corona Meninggal di Cianjur" dan "WNI Positif Corona, Kenali Cara Pencegahannya" diunduh tanggal 3 Maret 2020 pukul 14.30 WIB. Hasil dari analisis jenis paragraf berdasarkan letak pikiran utama dan kalimat topik, paragraf deduktif mendominasi paragraf dalam surat kabar. Jenis paragraf yang mendominasi dari kedua surat kabar adalah paragraf deduktif dengan jumlah empat paragraf. Jenis paragraf induktif dari kedua surat kabar berjumlah satu paragraf. Jenis paragraf deduktif-induktif dari kedua surat kabar berjumlah satu paragraf, dan jenis paragraf induktif-deduktif dari kedua surat kabar berjumlah dua paragraf.
\end{abstract}

Kata Kunci: paragraf, virus corona, surat kabar online.

\section{Pendahuluan}

Paragraf tidak terlepas dari wacana. Wacana terdiri dari beberapa paragraf yang memiliki makna kohesi dan koherensi satu sama lain. Kridalaksana (2008:259) mengatakan bahwa wacana direalisasikan dalam karangan yang utuh (novel, buku, seri ensiklopedia, dan sebagainya), paragraf, kalimat atau kata yang membawa amanat yang lengkap. Berkaitan dengan wacana Goziyah (2018:1) wacana memiliki pengertian sebagai media komunikasi berbentuk lisan maupun tulisan yang dapat dipahami oleh komunikator (pembicara/penulis dan komunikan (penyimak/pembaca). Wacana juga merupakan hasil dari suatu karya tulis. Penelitian mengenai jenis paragraf sudah pernah dilakukan oleh Rera Sarah Rizky Haryanti tentang surat kabar 
kompas Nomor 156 Desember 2019. Namun, pada penelitian ini objeknya yaitu jenis surat kabar online sedangkan, persamaan dalam penelitian ini terletak pada apa yang dikaji yaitu jenis paragraf dalam surat kabar. Maka dari itu wacana tidak terlepas dari paragraf dan paragraf merupakan bagian dari karya tulis.

Karya tulis dalam penyusunannnya perlu memperhatikan aturan atau kaidah kebahasaan yang telah ditentukan. Kaidah kebahasaan tersebut, mengenai aturan tata penulisan dari segi ejaan, kosa kata, penyusunan kalimat yang efektif, dan paragraf yang tersusun secara sistematis. Apabila suatu karya tulis tidak tersusun sistematis, maka setiap topik yang terdapat dalam paragraf tidak berkembang dengan baik. Seorang menulis dalam mengembangkankan paragraf, bebas untuk mengekspresikan gagasannya dan tidak lupa menggunakan bahasa yang mudah dipahami oleh pembaca.

Widjono (2008:173) mengungkapkan paragraf satuan bahasa tulis yang terdiri beberap kalimat yang tersusun secara runtut, logis, dalam satu kesatuan ide yang tersusun secara lengkap, utuh, dan padu". Hal tersebut menjelaskan bahwa paragraf merupakan bagian tertinggi dan luas dari kalimat karena, paragraf menyusun kalimat dengan mengutamakan ide pokok yang akan dikembangkan, sehingga timbul kesatuan antar kalimat yang utuh. Selain itu, Chaer (2011:27) menjelaskan bahwa paragraf kesatuan bahasa yang dibangun oleh dua buah kalimat atau lebih yang secara semantis dan sintaksis merupakan suatu kesatuan yang utuh. Sedangkan, Achmad dan Alex (2016:125) paragraf adalah bagian dari suatu karangan yang memiliki satu pikiran utama yang dinyatakan dengan kalimat topik yang dirangkaikan dengan kalimat pendukung atau penjelas yang runtut, logis, jelas, dan memenuhi persyaratan gramatikal dalam membangun satu kesatuan makna yang utuh (wroles meaning). Kalimat-kalimat dalam paragraf memperlihatkan kesatuan pikiran atau mempunyai keterkaitan dalam membentuk gagasan atau topik tersebut (Arifin dan Aswinarko, 2012:94). Hal tersebut menjelaskan bahwa paragraf merupakan suatu karangan yang memiliki gagasan atau topik pada susunan paragraf. Oleh karena itu, 
paragraf berisi rangkaian suatu topik yang menjelaskan gagasan yang dituangkan pada tulisan sehingga menghasilkan suatu karya yang dalam segi penyusunannya bersifat runtut, antar kalimat dalam paragraf saling memiiki kaitan satu sama lain, karena paragraf bagian terbesar dari suatu kalimat.

Menurut Widjono (2008:176) jenis paragraf berdasarkan letak pikiran utama dan kalimat topik terbagi menjadi dua bagian. Pertama, paragraf tanpa kalimat topik, jenis paragraf ini menjelaskan bahwa kalimat-kalimat yang terdapat pada paragraf memiliki kesetaraan atau kedudukan yang sama pada paragrafnya. Pada paragraf ini tidak terdapat kalimat utama dan kalimat penjelas. Kedua, kalimat topik pada paragraf, jenis paragraf ini menerangkan penempatan kalimat topik dilakukan dengan beberapa variasi. Penempatan kalimat topik bisa berada pada awal, akhir, awal dan akhir, dan tengah paragraf. Hal tersebut dilakukan agar pembaca bisa menalar pembahasan yang terdapat pada paragraf. Kalimat topik pada awal paragraf sering disebut sebagai paragraf deduktif. Paragraf deduktif adalah suatu kalimat atau topik utama yang berada dalam awal paragraf dan bersifat umum. Kalimat topik pada akhir paragraf sering disebut paragraf induktif. Paragraf induktif adalah suatu paragraf yang diakhiri kalimat topik dan diawalai dengan kalimat penjelas. Kalimat topik pada awal dan akhir paragraf sering disebut dengan paragraf deduktif-induktif. Paragraf deduktif-induktif adalah kalimat topik pada awal paragraf dan juga terdapat diakhir paragraf. Kalimat topik pada tengah paragraf disebut paragraf induktif-deduktif. Induktif-deduktif adalah kalimat topik terdapat di tengah paragraf yang diawali dengan kalimat penjelas dan diakhir paragraf diakhri dengan kalimat penjelas. Masing-masing penempatan kalimat topik dalam sebuah paragraf berpengaruh terhadap pembahasan yang dikembangkan.

Paragraf terdapat dalam sebuah berita dan setiap berita memiliki kalimat yang dikembangkan dalam sebuah paragraf. Penulisan suatu berita tidak terlepas dari susunan paragraf. Menurut Wirnani dan Rani (2019:85) menjelaskan "berita merupakan produk utama jurnalistik dalam memenuhi kebutuhan naluri manusia 
yang ingin tahu dalam memberikan informasi kepada khalayak tentang suatu peristiwa. Hal tersebut menjelaskan bahwa berita merupakan konsumsi publik mengenai informasi yang akan disampaikan. Berita dipubikasikan di media masa, baik secara online maupun melalui media cetak. Perkembangan teknologi dan komunikasi membuat berita lebih banyak disebarkan melalui media online. Saat menulis berita penulis harus memperhatikan kaidah dalam menulis, seperti menguasai ejaan, kosa kata, mengatur sebuah kalimat, dan paragraf berdasarkan ketentuan.

\section{Metode Penelitian}

Penelitian ini menggunakan pendekatan kualitatif. pendekatan kualitatif penelitian yang secara primer menggunakan paradigma pospositivist dalam mengembangkan ilmu pengetahuan (seperti pemikiran tentang sebab-akibat, reduksi kepada varibael, hipotesis, dan pertanyaan spesifik, menggunakan pengukuran dan observasi serta pengujian teori), menggunakan strategi penelitian seperti eksperimen dan survei yang memerlukan data statistikMetode yang digunakan dalam penelitian ini menggunakan metode analisis isi (Emzir, 2015:28). Sulaeman dan Goziyah (2019:226) menyatakan bahwa analisis isi merupakan pesan atau informasi yang diperoleh dicatat secara sistematis, kemudia diinterpretasikan oleh peneliti, adapun dalam penelitian analisis isi objektivitas peneliti sangat diperlukan agar pemahaman mengenai sebuah isi dapat benar-benar terwujud. Data yang digunakan dalam penelitian ini berupa data sekunder dengan mengambil data tidak secara langsung diperoleh. Data sekunder sumber data yang diperoleh dengan cara membaca, mempelajari, memahami melalui media lain yang bersumber dari literature, bukubuku serta dokumen. Data sekunder pada penelitian ini menggunakan buku-buku referensi dan objek penelitian. Husein (2005:303) mengungkapkan objek penelitian berkaitan dengan apa atau siapa yang menjadi objek penelitian. Juga di mana dan kapan penelitian dilakukan, bisa juga ditambahkan hal-hal lain jika perlu. Objek penelitian yang menjadi rujukan analisis yaitu media surat kabar online CNN Indonesia diunduh hari selasa tanggal 03 Maret 2020 pukul 14.30 WIB bertema 
tentang virus corona yang baru-baru ini sedang hangat dibicarakan. Objek yang digunakan sebagai objek analisis menggunakan dua objek yaitu dua teks berita yang berjudul "Telkom Konfirmasi Suspect Virus Corona Meninggal di Cianjur" dan "WNI Positif Corona, Kenali Cara Pencegahannya".

\section{Pembahasan}

Penelitian ini menganalisis macam-macam paragraf pada dua teks surat kabar dari CNN Indonesia yang diunduh pada hari selasa tanggal 03 Maret 2020 pukul 14.30 WIB bertema tentang virus corona.

\section{Telkom Konfirmasi Suspect Virus Corona Meninggal di Cianjur}

Pada berita ini terdapat empat paragraf yang sudah dianalisis yaitu:

Paragraf (1) Suspect corona adalah istilah medis yang menyatakan seorang pasien diduga mengidap corona, tapi belum bisa dipastikan positif atau negatif. Vice President Corporate Communication Telkom Arif Prabowo mengatakan berdasarkan riwayat medis yang tercatat di perusahannya 10 tahun terakhir, diketahui karyawan Telkom itu sering mengalami radang saluran nafas dan batuk pilek. "Adapun penyebab meninggalnya terkait dengan dugaan akibat infeksi virus corona (Covid-19), saat ini kami sedang berkoordinasi intensif dengan Kementerian Kesehatan untuk mendapatkan hasil pemeriksaan laboratorium," tulis Arif melalui keterangan rilis yang diterima CNNIndonesia.com.

Dari keterangan paragraf pertama, paragraf tersebut termasuk kedalam paragraf deduktif karena kalimat utama yang terdapat pada paragraf terletak pada awal paragraf. Kalimat utama berisikan pernyataan umum mengenai perkiraan atau dugaan sementara mengenai orang yang terjangkir corona biasa disebut dengan suspect corona. Kalimat selanjutnya adalah kalimat khusus, kalimat khusus berfungsi sebagai kalimat penjelas. 
Paragraf (2) sebelumnya, Kabag Humas dan Protokoler Setda Cianjur, Iyus Yusuf menyebut D sempat berkunjung ke Malaysia. Malaysia sendiri merupakan salah satu negara yang dilaporkan sudah memiliki 29 warga yang terinfeksi virus corona Covid-19. Warga yang terjangkit virus corona di Malaysia sempat bepergian ke Milan, Italia, dan China. Lebih lanjut kata Arif, sejak wabah corona makin meluas, Telkom telah melakukan sejumlah upaya pencegahan seperti menyampaikan himbauan kepada seluruh karyawan untuk tidak melakukan perjalanan ke luar negeri.

Dari keterangan paragraf kedua, paragraf tersebut termasuk ke dalam paragraf induktif, karena kalimat utama yang terdapat pada paragraf terletak pada akhir paragraf. Kalimat awal pada paragraf tersebut merupakan kalimat penjelas dari kalimat utama paragraf, karena dalam paragraf induktif kalimat awal merupakan pernyataan penjelas. Pernyataan umum mengenai paragraf kedua berisikan pencegahan dan himbauan kepada karyawan Telkom untuk tidak melakukan perjalanan keluar negeri karena dampak penyakit virus corona.

Paragraf (3) Selain itu, Arif dan jajarannya juga aktif mensosialisasikan pengenalan dan pencegahan gejala penyakit COVID-19, mengimbau karyawan untuk memantau perkembangan penyebaran corona lewat media informasi yang resmi, dan mengaktifkan posko yang melibatkan tenaga medis serta call center yang dapat dihubungi 24 jam. "Selanjutnya perusahaan akan lebih mengintensifkan upaya-upaya preventif yang telah dilakukan berkoordinasi dengan dinas kesehatan setempat, termasuk menurunkan tenaga medis dari Yayasan Kesehatan Telkom di setiap lokasi kerja karyawan untuk melakukan pemeriksaan awal guna pencegahan secara lebih dini, " pungkas Arif.

Dari keterangan paragraf ketiga, paragraf tersebut termasuk kedalam paragraf deduktif karena kalimat utama yang terdapat pada paragraf terletak pada awal paragraf. Kalimat utama berisikan pernyataan umum mengenai mensosialisasikan 
pengenalan dan pencegahan penyakit COVID-19. Kalimat selanjutnya adalah kalimat khusus, kalimat khusus berfungsi sebagai kalimat penjelas.

Paragraf (4) Karyawan Telkom berinisial D itu merupakan warga Bekasi yang sedang berkunjung ke rumah keluarganya di Cianjur. Iyus menjelaskan objek darah warga berinisial D itu sudah dikirim ke Jakarta tapi hasil pemeriksaan belum diketahui. Kemarin, dua WNI berdomisili di Depok dinyatakan positif virus corona dan tengah mendapat perawatan di Rumah Sakit Sulianti Saroso (RSPI) Jakarta Utara.Keduanya tertular virus corona setelah berinteraksi dengan warga negara Jepang

Dari keterangan paragraf keempat, paragraf tersebut termasuk kedalam paragraf deduktif karena kalimat utama yang terdapat pada paragraf terletak pada awal paragraf. Kalimat utama berisikan pernyataan umum mengenai mengsosialisasikan pengenalan dan pencegahan penyakit COVID-19. Kalimat selanjutnya adalah kalimat khusus, kalimat khusus berfungsi sebagai kalimat penjelas.

\section{WNI Positif Corona, Kenali Cara Pencegahannya}

Pada berita ini terdapat lima paragraf yang sudah dianalisis yaitu:

Paragraf (1) Presiden Joko Widodo mengungkapkan, seorang ibu (64) dan putrinya (31) terinfeksi setelah berkontak dengan seorang warga negara (WN) Jepang yang positif virus corona. "Tadi pagi saya mendapat laporan dari Pak Menkes [Terawan] bahwa ibu ini dan putrinya positif corona," kata Jokowi di Jakarta, Senin (2/3). Saat ini, dua orang positif virus corona telah dirawat di RSPI Sulianti Saroso, Jakarta Utara. Dengan telah terkonfirmasinya virus corona di Indonesia, kita harus lebih waspada. Berikut beberapa langkah yang bisa Anda ambil untuk melindungi diri dari virus corona.

Dari keterangan paragraf pertama, paragraf tersebut termasuk kedalam paragraf deduktif karena kalimat utama yang terdapat pada paragraf terletak pada 
awal paragraf. Kalimat utama berisikan pernyataan umum mengenai korban terduga virus corona yang diungkapkan oleh Bapak Jokowi. Kalimat selanjutnya adalah kalimat khusus, kalimat khusus berfungsi sebagai kalimat penjelas.

Paragraf (2) Mencuci tangan memang terlihat sepele. Namun, baik Kementerian Kesehatan maupun Organisasi Kesehatan Dunia (WHO) mendorong semua orang untuk rajin mencuci tangan. Tangan merupakan 'alat transportasi' kuman, bakteri, dan virus untuk masuk ke dalam tubuh. Tanpa sadar, orang kerap memegang mulut, hidung, dan mata dalam kondisi tangan tidak steril.

Dari keterangan paragraf kedua, paragraf tersebut termasuk kedalam paragraf induktif-deduktif karena kalimat utama yang terdapat pada paragraf terletak di tengah paragraf berarti diawali dengan kalimat penjelas dan diakhiri dengan kalimat penjelas. Paragraf ini menerangkan tentang pentingnya mencuci tangan.

Paragraf (3) Anda disarankan untuk mencuci tangan sebelum memegang mulut, hidung, dan mata. Apalagi jika sebelumnya Anda baru menyentuh beberapa fasilitas publik. Jangan lupa juga mencuci tangan sebelum makan. Cuci tangan dengan sabun antiseptik. Agar hasilnya maksimal, gosok tangan selama sekitar 20 detik atau setara dengan lagi "Happy Birthday".

Dari keterangan paragraf ketiga, paragraf tersebut termasuk kedalam paragraf deduktif karena kalimat utama yang terdapat pada paragraf terletak pada awal paragraf. Kalimat utama berisikan pernyataan umum mengenai saran untuk mencuci tangan sebelum memegang mulu, hidung, dan mata. Kalimat selanjutnya adalah kalimat khusus, kalimat khusus berfungsi sebagai kalimat penjelas.

Paragraf (4) Saat batuk dan bersin, tutup hidung dan mulut Anda dengan tisu atau sapu tangan. Ini untuk mencegah penularan penyakit lewat udara. Hindari menutup hidung dan mulut dengan tangan. Sebab tanpa sadar tangan malah 
memindahkan bibit penyakit lewat benda-benda yang disentuh. Jika tidak ada tisu atau sapu tangan, tutup hidung dan mulut dengan siku tangan bagian dalam.

Dari keterangan paragraf keempat, paragraf tersebut termasuk kedalam paragraf deduktif-induktif karena kalimat utama yang terdapat pada awal dan akhir paragraf. Kalimat utama pada awal paragraf dan akhir paragraf merupakan suatu bentuk penegasan terhadap topik yang dibicarakan. Kalimat pada awal paragraf memiliki sifat deduktif dan diakhir paragraf memiliki sifat induktif. Paragraf ini menerangkan tentang pentingnya menutup hidup dan mulut ketika batuk.

Paragraf (5) Kenaikan suhu tubuh jadi penanda atau gejala suatu penyakit termasuk infeksi virus corona. Penting untuk selalu memantau suhu tubuh. "Suhu normal tubuh itu 37,2 derajat Celcius. Lebih dari itu sudah tergolong tinggi. Sebaiknya, periksakan ke dokter dan istirahat di rumah," kata dokter spesialis paru RSPI Sulianti Saroso, Adria Rusli dalam Sosialisasi Penyakit Virus Corona di CT Corp, Jakarta beberapa waktu lalu.

Dari keterangan paragraf kelima, paragraf tersebut termasuk kedalam paragraf deduktif karena kalimat utama yang terdapat pada paragraf terletak pada awal paragraf. Kalimat utama berisikan pernyataan umum mengenai kenaikan suhu badan dan batuk merupakan gejala viruscorona. Kalimat selanjutnya adalah kalimat khusus, kalimat khusus berfungsi sebagai kalimat penjelas.

\section{Simpulan}

Paragraf memiliki banyak ragamnya dan dapat dikualifikasi dalam beberapa bagian, yaitu letak topiknya, pembahasannya serta strukturnya. Dalam dua teks berita yang telah diteliti, peneliti telah menemukan beberapa macam jenis paragraf menurut topiknya yang membuat teks berita menjadi lebih menarik untuk dibaca, dan juga memudahkan pembaca dalam memahami topik berita yang sedang dibahas dalam berita ini, yang berfokus pada berita tentang virus corona yang sedang hangat. Sedangkan, untuk macam-macam paragraf sesuai topiknya dibagi menjadi empat 
bagian yaitu paragraf deduktif, induktif, deduktif-induktif, dan induktif-deduktif itu semua dibedakan berdasarkan posisi dari topik utama pembicaraan yang akan dibahas dalam teks.

Dari hasil penelitian peneliti dapat menyimpulkan bahwa setiap teks berita memiliki struktur topik pembahasan diawal paragraf (deduktif), dikarenakan teks berita cenderung memiliki sifat yang harus menarik minat pembaca, maka dari itu awal paragraf sebetulnya adalah kunci untuk membuat teks berita jauh topik lebih menarik untuk para pembacanya, ini sama halnya dengan judul dari teks berita yang tidak boleh membuat pembaca menjadi penasaran untuk membaca dan memahami isi berita. Hasil dari analisis jenis paragraf berdasarkan letak pikiran utama dan kalimat topik, paragraf deduktif mendominasi jenis paragraf dalam surat kabar berjudul “Telkom Konfirmasi Suspect Virus Corona Meninggal di Cianjur" dan "WNI Positif Corona, Kenali Cara Pencegahannya”. Jenis paragraf yang mendominasi dari kedua surat kabar adalah paragraf deduktif dengan jumlah empat paragraf. Jenis paragraf induktif dari kedua surat kabar berjumlah satu paragraf. Jenis paragraf deduktifinduktif dari kedua surat kabar berjumlah satu paragraf, dan jenis paragraf induktifdeduktif dari kedua surat kabar berjumlah dua paragraf.

\section{Daftar Pustaka}

Achmad dan Alex. 2016. Bahasa Indonesia untuk Perguruan Tinggi Substansi Kajian dan Penerapannya. Jakarta: Erlengga.

Arifin, E. Zaeni dan Aswinarko. 2012. Penyuntingan Naskah. Tangerang: PT. Pustaka Mandiri.

Chaer, Abdul. 2011. Ragam Bahasa Ilmiah. Jakarta: Rineka Cipta.

CNN Indonesia. 2020. WNI Positif Corona, Kenali Cara Pencegahannya. Diunduh pada hari selasa tanggal 03 Maret 2020 pukul 14.30 WIB. https://www.cnnindonesia.com/gaya-hidup/20200302143922-255-479757/wnipositif-corona-kenali-cara-pencegahannya.

CNN Indonesia. 2020. Telkom Konfirmasi Suspect Virus Corona Meninggal di Cianjur. Diunduh pada hari selasa tanggal 03 Maret 2020 pukul 14.30 WIB. 
https://www.cnnindonesia.com/teknologi/20200303115415-185-480031/telkomkonfirmasi-suspect-virus-corona-meninggal-di-cianjur

Emzir. 2015. Metodologi Peelitian Pendidikan: Kuantitatif dan kualitatif. Jakarta. Rajawali Pers.

Goziyah. 2018. Studi Wacana Bahasa Indonesia (Kajian Wacana Kritis). Tangerang: Universitas Muhammadiyah Tangerang.

Husein, Umar. 2005. Metode Penelitian Untuk Tesis dan Bisnis. Jakarta: Grafindo.

Kridalaksana, Harimurti. 2008. Kamus Linguistik. Jakarta: Gramedia Pustaka Utama.

Sulaeman, Agus dan Goziyah. 2019. Metodologi Penelitian Bahasa dan Sastra. Jakarta Timur: Edu Pustaka.

Sugiyono. 2012. Memahami Penelitian Kualitatif. Bandung: ALFABETA.

Widjono, Hs. 2008. Bahasa Indonesia Mata Kuliah Pengembangan Kepribadian di Perguruan Tinggi. Jakarta: PT. Grasindo.

Winarni dan Rani Dwi Lestari. 2019. Sumber Berita Netizen dalam Perspektif Etika Jurnalistik (Studi Kasus pada Media Online Jogja.trimbunnews.com). Jurnal Pekomnas. Universitas Mercu Buana Yogyakarta. Vol 4 No 12019 Hal 8596. 